\title{
DINAMIKA DAN TANTANGAN PENGGUNAAN DAN PEMANFAATAN TANAH DI WILAYAH PULAU KECIL
}

\author{
The Dynamics and Challenges of Land Use and Utilization on Small Island
}

\author{
Sukmo Pinuji ${ }^{1}$, Muh Arif Suhattanto ${ }^{1}$, Tjahjo Arianto ${ }^{1}$ \\ 'Sekolah Tinggi Pertanahan Nasional \\ Jl. Tata Bumi No 5, Gamping, Sleman, Daerah Istimewa Yogyakarta \\ *Email: sukmo.pinuji@stpn.ac.id; suhatt@yahoo.com; \\ tjahjoarianto@gmail.com
}

\begin{abstract}
Small island land resource management has specific characteristic, differ from its main island, due to its geographical characteristic. Moreover, small Island is also vulnerable due to climate changes. Located on Sumenep District, East Java, Masalembu is one of the example of inhabited small island in Indonesia, represent the dynamic and land use management in small island area. This research use DPSIR (drivers, pressures, states, impacts, and responses) method to capture those dynamics. The results show that the dynamics of land use and utilization in Masalembu are described as follow: (i) land use and utilization activities are highly influenced by economic growth, climate change due to the fluctuation of marine products, and population growth; (ii) climate change, together with exploitation of marine resources, resulting the decrease of marine products, thus drive the population to start and to cultivate the land for improving their income. In the long run, land products from agriculture and farming sectors become competitive commodities beside fisheries; (iii) the absence of zonation, strategic, and action plans on land use and utilization control giving the consequences of unstructured, unplanned, and unsustainable land use and utilization.
\end{abstract}

Keywords: small island, sustainable small island, DPSIR, small island spatial planning.

Intisari: Pengelolaan sumberdaya tanah di pulau kecil memiliki ciri khusus yang berbeda dengan pulau induk, terkait karakteristik geografisnya. Selain itu, pulau kecil juga memiliki kerentanan terhadap fenomena perubahan iklim. Masalembu, merupakan salah satu contoh dari ribuan pulau kecil berpenghuni di Indonesia yang dapat mewakili gambaran dinamika pengelolaan dan pemanfaatan lahan di wilayah pulau kecil. Penelitian ini menggunakan metode DPSIR (drivers, pressures, states, impacts, dan responses) untuk menangkap gambaran dinamika tersebut. Hasil penelitian menunjukkan bahwa dinamika penggunaan dan pemanfaatan lahan di Pulau Masalembu dapat dilihat sebagai berikut: (i) aktivitas penduduk atas tanah sangat dipengaruhi oleh pertumbuhan ekonomi, perubahan iklim yang menyebabkan pasang surutnya hasil perikanan laut, dan pertumbuhan penduduk baik yang terjadi karena kelahiran maupun migrasi; (ii) perubahan iklim serta eksploitasi sumberdaya laut yang berlebihan sehingga tidak dapat lagi memenuhi kebutuhan ekonomi masyarakat, menjadi faktor pendorong masyarakat untuk mulai memanfaatkan tanah sebagai alternatif penghasilan, yang kemudian beralih menjadi komoditas unggulan, serta (iii) tidak adanya rencana zonasi dan rencana strategis penggunaan dan pemanfaatan tanah membuat pola-pola penggunaan dan pemanfaatannya menjadi tidak terstruktur dan terencana, serta tidak memenuhi prinsip sustainability.

Kata Kunci: pulau kecil, sustainable small island, DPSIR, tata ruang pulau kecil. 


\section{A. Pendahuluan}

Pulau kecil memiliki karakteristik yang spesifik jika dibandingkan dengan wilayah daratan pada umumnya. Selain luas wilayahnya yang terbatas, pulau kecil juga memiliki kerentanan yang disebabkan oleh kondisi geografisnya, baik dari segi biofisik maupun sosial-ekonomi (Abeyratne 1999; Briguglio 1995; Velde, Green, Vanclooster \& Clothier 2007). Pada umumnya, pulau kecil memiliki ketergantungan yang tinggi dengan wilayah daratan induknya baik dari segi ekonomi, sosial, dan pelayanan kemasyarakatan seperti fasilitas kesehatan, pendidikan, administrasi pemerintahan, dan lain sebagainya (Huang 1997; Kerr 2005; Sutton \& Payne 1993). Selain itu, pulau kecil juga memiliki kerentanan terhadap bencana alam dan perubahan iklim, baik yang bersifat lokal maupun global, yang akan berpengaruh terhadap kelangsungan kehidupan ekosistem pada aras lokal. Perubahan iklim akan berakibat pada naiknya air laut, intrusi air laut ke dalam air tanah yang akan mengganggu stabilitas sumber air bersih bagi ekosistem, termasuk pula berpengaruh pada ekosistem laut dan hasil tangkapan ikan yang merupakan sumber mata pencaharian bagi sebagian besar penduduk pulau kecil. Selain itu, pulau kecil juga memiliki kerentanan terhadap eksploitasi sumberdaya alam, baik daratan maupun lautan, yang akan berpengaruh terhadap stabilitas ekosistem yang merupakan kunci dari keberlangsungan sebuah pulau kecil. Sebagai sebuah negara kepulauan, Indonesia, yang merupakan wilayah negara kepulauan, memiliki 111 pulau kecil terluar yang menjadi penanda batas wilayah $\mathrm{NKRI}^{1}$, memiliki tugas

1 Ditetapkan melalui Keppres Nomor 6 Tahun 2017 tentang Penetapan Pulau Kecil Terluar. Pada mulanya, melalui PP Nomor 38 Tahun 2002 yang diubah dengan PP Nomor 37 Tahun 2008, Indonesia memiliki 92 pulau terluar yang berat dalam mengelola pulau-pulau kecil yang ada di wilayah NKRI untuk menjamin keberlangsungannya.

Dalam dunia internasional, tahun 1992, United Nations telah menetapkan 57 negara yang termasuk ke dalam Small Island Developing States (SIDS), dan sejak tahun 2015, SIDS merupakan salah satu bagian dari agenda Sustainable Development Goals yang ditetapkan oleh UN. Meskipun Indonesia memiliki 16.056 pulau yang terdaftar dalam daftar $\mathrm{UN}^{2}$, dimana sebagian besarnya merupakan pulau kecil dan berpenghuni (data terakhir yang diperoleh menyebutkan bahwa sebanyak 2.342 pulau kecil berpenghuni, dan tersebar di 18 provinsi), Indonesia bukanlah bagian dari SIDS. Dengan jumlah sebanyak tersebut, penataan dan pelembagaan wilayah pulau kecil menjadi penting untuk dilakukan, dan tidak hanya sebatas pada wilayah laut dan sumber daya lautan, tetapi juga sumberdaya daratan yang mereka miliki. Mengingat karakteristik geografis wilayah NKRI yang merupakan wilayah kepulauan, sangatlah penting untuk mengafiliasi kondisi khusus tersebut dalam melakukan penataan pertanahan di wilayah khusus pulau-pulau kecil.

Undang-Undang Nomor 27 Tahun 2007 tentang Pengelolaan Wilayah Pesisir dan Pulau-Pulau Kecil mendeskripsikan pulau kecil sebagai wilayah pulau yang memiliki luas kurang dari atau sama dengan 2000 $\mathrm{km}^{2}$ beserta seluruh kesatuan ekosistemnya. Pengelolaan wilayah pulau kecil tersebut

yang digunakan sebagai batas penanda wilayah NKRI.

2 Jumlah ini bertambah 2.590 pulau dari data tahun 2012 sebanyak 13.466 pulau. Indonesia melakukan pendaftaran dan pendataan pulau dalam konferensi ke-11 UNCSGN (United Nations Conference on the Standardization of Geographical Names), yang diadakan setiap 5 tahun sekali. 
dilakukan dalam bentuk penyusunan Rencana Strategis Wilayah Pesisir dan Pulau-Pulau Kecil (RSWP-3-K), Rencana Zonasi Wilayah Pesisir dan Pulau-Pulau Kecil (RZWP-3-K), Rencana Pengelolaan Wilayah Pesisir dan Pulau-Pulau Kecil (RPWP-3K), dan Rencana Aksi Pengelolaan Wilayah Pesisir dan PulauPulau Kecil (RAPWP-3K), yang berlaku selama 20 tahun dan ditinjau setiap 5 tahun sekali. Dalam implementasinya, UndangUndang Nomor 1 Tahun 2014 mengamanatkan bahwa penyusunan RZWP-3-K merupakan kewenangan pemerintah provinsi, termasuk juga pengelolaan dan pengawasannya. Meskipun begitu, implementasi di lapangan belum dapat berjalan dengan maksimal, terkendala oleh beberapa faktor baik yang bersifat institusional kelembagaan, sumberdaya maupun peraturan. Di lain pihak, tuntutan untuk melakukan pengaturan terhadap pemanfaatan dan penggunaan tanah yang mencakup prinsip sustainable baik secara ekonomi, sosial maupun lingkungan sangat perlu untuk segera dilakukan.

Tulisan ini bermaksud untuk menguraikan dinamika dan tantangan dalam pengaturan penggunaan dan pemanfaatan tanah di wilayah pulau kecil. Penelitian dilakukan dalam bentuk studi kasus, dengan mengambil sampel di Pulau Masalembu, Kabupaten Sumenep, Provinsi Jawa Timur. Fokus pembahasan ditujukan pada keberagaman kondisi sosial ekonomi masyarakat, kondisi fisik geografis, serta bagaimana konfigurasi tersebut berpengaruh terhadap pola-pola penggunaan dan pemanfaatan tanah di wilayah tersebut.

Seperti halnya pulau kecil lainnya, Pulau Masalembu memiliki beberapa masalah terkait dengan terbatasnya kondisi geografis yang dimiliki. Dengan luas wilayah yang hanya sebesar 3,18 km², Masalembu harus menyokong kebutuhan atas tanah yang terbagi menjadi wilayah permukiman, pertanian/perkebunan, peternakan, kawasan ekonomi dan perdagangan, serta kawasan penyangga sebagai buffer ekosistem untuk menjaga keberlanjutan daya dukung tanah di masa depan. Rencana alokasi tanah yang berkelanjutan serta dapat mengakomodasi kepen-tingan mitigasi dan adaptasi terhadap perubahan iklim sangat penting untuk diterapkan. Di lain pihak, sampai saat ini, belum disusun rencana strategis, rencana zonasi, dan rencana aksi peruntukan dan penggunaan tanah. Untuk tujuan tersebut, perlu dilakukan rencana identifikasi terhadap dinamika penggunaan dan pemanfaatan tanah di wilayah pulau kecil, yang dapat dikategorisasikan baik secara ekonomi, sosial, maupun dalam konteks kelestarian lingkungan hidup.

Untuk memudahkan sistematika berpikir dalam melakukan analisis, dalam menelaah dinamika penggunaan tanah digunakan metode DPSIR yang dikembangkan oleh European Environment Agency (EEA) dan sudah luas digunakan untuk melakukan analisis terkait lingkungan hidup dan daya dukung lingkungan (Giupponi 2002). Metode DPSIR dilakukan dengan menguraikan driving force (faktor penyebab), pressure (tekanan/ faktor pendorong/katalis yang mempercepat perubahan kondisi suatu keadaan), states (kondisi awal), impact (dampak dari perubahan tersebut), serta responses (respon dari stakeholder/subjek terkait terhadap perubahan tersebut). Dengan menguraikan permasalahan dan kompleksitas penggunaan dan pemanfaatan tanah di wilayah Pulau Masalembu ini, analisis terhadap dinamika yang ada serta rekomendasi serta strategi untuk menghadapinya dapat lebih mudah dirumuskan secara komprehensif dan sistematis.

Secara visual, framework konseptual dari metode DPSIR ditunjukkan oleh Gambar 1 berikut. 
Gambar 1. Skema Konseptual Model DPSIR (Smeeth \& Weterings, 1999)

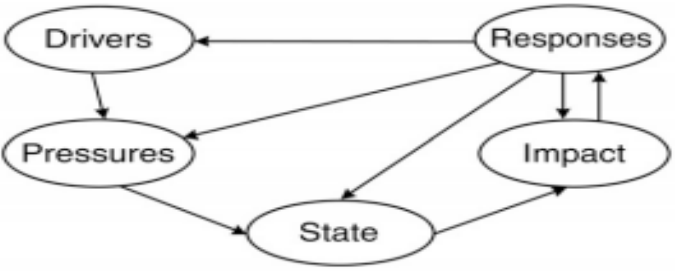

Penggunaan metode DPSIR ini sangat bermanfaat dalam menentukan strategi penyelesaian masalah lingkungan, guna mengambil keputusan berdasarkan hasil formulasi hubungan antara aktivitas manusia yang terdiri dari beberapa sektor dengan lingkungan hidup, yang dipandang sebagai sebuah rantai keterikatan (Giupponi 2002). Hal tersebut digambarkan pada Gambar 2 berikut.

Gambar 2. Hubungan dan Keterkaitan antara Komponen DPSIR dalam Pengambilan Keputusan untuk Berbagai Permasatanah Lingkungan (Giupponi 2002)

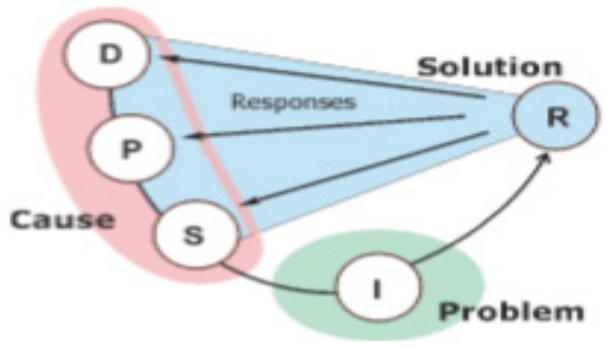

\section{B. Dinamika Penggunaan dan Pemanfaatan Tanah di Masalembu}

\section{Sekilas tentang Masalembu}

Masalembu merupakan sebuah kecamatan yang termasuk dalam wilayah administratif Kabupaten Sumenep, Provinsi Jawa Timur. Kecamatan Masalembuterdiridari3 (tiga) pulau, yaitu Pulau Masalembu, Pulau Masakambing, dan Pulau Karamian. Lokasi pulau tersebut terletak di perairan Laut Jawa, di antara Pulau Kalimantan dan Sulawesi. Pulau Masalembu, yang memiliki luas wilayah sebesar $3.18 \mathrm{~km}^{2}$, adalah yang paling besar di antara ketiga pulau tersebut, dan merupakan pusat pemerintahan serta pusat aktivitas ekonomi bagi Kecamatan Masalembu. Pulau ini dapat dicapai melalui 2 (dua) pelabuhan, yaitu dari Pelabuhan Tanjung Perak di Surabaya dan Pelabuhan Kalianget di Sumenep. Tiga kapal perintis yang dikelola oleh Pelni melayani jalur pemberangkatan dari dan ke Masalembu setiap 5 (lima) hari sekali, yang sangat tergantung pada kondisi cuaca dan kondisi perairan di sekitar Masalembu. Dari kedua pelabuhan tersebut, Masalembu dapat dicapai dengan $10-12$ jam perjalanan, tergantung pada kondisi cuaca. Lokasi wilayah penelitian Pulau Masalembu dapat dilihat pada Gambar 3 berikut.

Gambar 3. Lokasi Penelitian.

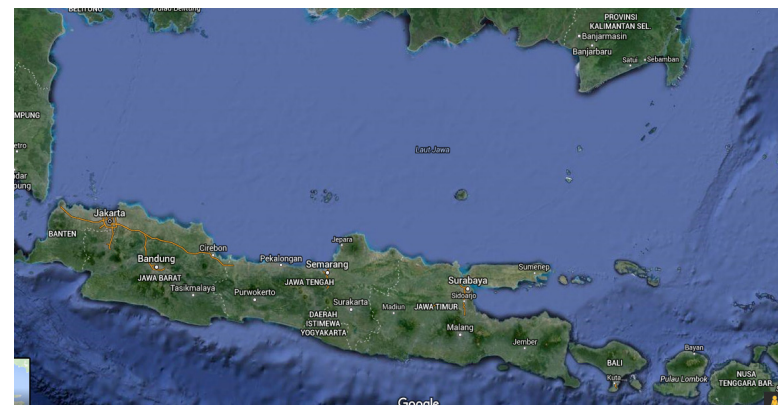

Akses utama Masalembu adalah dengan Surabaya dan Sumenep. Suplai bahan pokok dan kebutuhan ekonomi lainnya dipasok terutama dari Surabaya. Selain itu, hasil bumi dari Masalembu, seperti cengkih, pisang, kelapa, dan ternak sapi dikirim keluar pulau melalui Kalianget, Tanjung Perak, dan Batu Licin, Kalimantan.

Seluruh penduduk Pulau Masalembu adalah para pendatang yang kebanyakan berasal dari pulau-pulau besar di sekitarnya, seperti Jawa, Madura, Kalimantan, dan Sulawesi. Tak heran jika Masalembu menonjol dengan kondisi multi-etnisnya. Terdapat 3 (tiga) etnis yang paling dominan yang menghuni pulau ini, yang semuanya terkenal dengan budaya melaut dan merantau: Madura (dengan persentase $75 \%$ dari total penduduk), Bugis (15\%), dan Mandar (10\%). 
Sisanya adalah perantau dari Pulau Jawa, Sulawesi, dan sekitarnya. Mata pencaharian utama penduduk Masalembu adalah nelayan, meskipun saat ini sudah mulai bergeser pada perkebunan (kelapa, cabe jamu, dan cengkih). Dalam kurun waktu satu dekade terakhir, komoditas perkebunan serta peternakan menjadi 'primadona baru' bagi masyarakat Masalembu, ketika harga pasaran untuk komoditas ini mulai bernilai ekonomi tinggi di pasaran. Komoditas lain yang menonjol dari Masalembu adalah sapi. Beternak sapi, bagi etnis Madura, selain memiliki nilai tambah ekonomi, juga merupakan bagian dari budaya mereka sejak dulu. Sapi dari Pulau Masalembu memiliki pasaran yang bagus dan dipasok secara rutin ke wilayah Kalimantan. Pada tahun 2016, tercatat sejumlah 5000 ekor sapi telah diperdagangkan ke luar pulau, terutama ke Kalimantan melalui pelabuhan Batu Licin.

\section{Pemanfaatan Ruang di Pulau Masalembu}

Untuk mendeskripsikan pemanfaatan ruang di Pulau Masalembu, dilakukan kategorisasi penggunaan tanah menjadi 4 (empat) kelas, yaitu wilayah hutan, permukiman, padang rumput, dan perkebunan. Visualisasi penggunaan tanah dapat dilihat pada Gambar 4.

Gambar 4. Peta Penggunaan Tanah di Pulau Masalembu

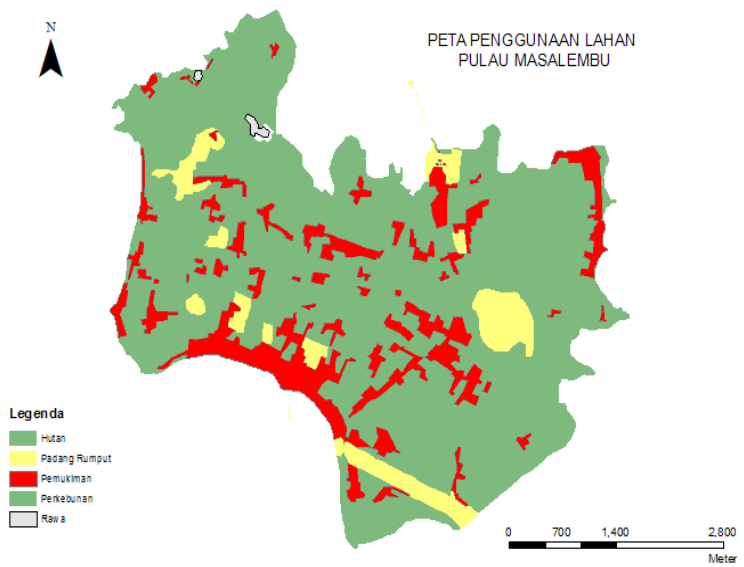

Sumber: Peta RBI Skala 1:25.ooo dengan dilakukan reklasifikasi dan generalisasi penggunaan tanah.

Pada peta yang ditunjukkan di Gambar 4 dapat dilihat bahwa penggunaan paling dominan dari wilayah tersebut adalah untuk perkebunan, diikuti dengan permukiman. Wilayah permukiman terutama terkonsentrasi diwilayah pesisir pantai di bagian selatan pulau, yang juga merupakan pintu masuk menuju Pulau Masalembu, dengan adanya dermaga di tempat tersebut. Wilayah sekitar dermaga di pesisir selatan pulau juga merupakan pusat kegiatan ekonomi, pusat pemerintahan dan fasilitas umum. Semakin ke tengah ke arah utara, kontur tanah semakin tinggi. Wilayah tengah didominasi oleh pegunungan berbatu, dan merupakan kawasan dengan sumber air bersih bagi seluruh pulau. Penduduk dengan etnis Madura, yang rata-rata selain bekerja sebagai nelayan juga berdagang, menjadi penghuni mayoritas daerah pesisir selatan. Semakin ke tengah, suku Mandar dan Bugis, yang lebih banyak melakukan aktivitas berkebun, mendiami daerah di wilayah pegunungan di bagian tengah pulau. Di wilayah Masalembu, etnis tertentu biasanya menghuni wilayah tertentu pula, sehingga dapat kita jumpai beberapa perkampungan yang dinamai berdasarkan mayoritas etnis yang ada di sana, seperti Kampung Mandar, Kampung Bugis, dan Kampung Raas.

Perkebunan di wilayah Masalembu didominasi dengan komoditas kelapa, cengkih, dan cabe jamu. Pada dekade tahun 1990 kelapa dan cabe jamu menjadi komoditas utama Masalembu. Selain bertani, masyarakat mulai beralih keperkebunan. Hutan dantanah kosong mulai dikonversi untuk menanam kelapa, cabe jamu, dan cengkih. Dalam waktu yang bersamaan, masyarakat juga mulai menyadari arti penting tanah, dan tanah mulai memiliki nilai ekonomi tinggi bagi mereka. Penduduk mulai memandang tanah sebagai komoditas yang memiliki nilai investasi tinggi, dan jual 
beli tanah, yang dulu belum marak, mulai terjadi. Investasi tanah ini terutama dilakukan untuk melakukan ekspansi kebun kelapa, di samping pula sebagai padang penggembalaan ternak dan sumber pakan ternak sapi.

Meskipun sektor perkebunan dilakukan secara intensif di wilayah Masalembu, pengelolaan perkebunan masih dilakukan secara tradisional. Masyarakat Masalembu, yang memiliki latar belakang nelayan dan kurang memiliki pengalaman dalam bercocok tanam dan mengelola pertanian secara otodidak. Tidak adanya pendampingan dari pemerintahdalamhalperkebunandanbercocok tanam sehingga pola pengelolaan tanah mereka cenderung over eksploitatif, dengan mengoptimalkan penggunaan pupuk dan bahan kimia lainnya yang dapat memberikan hasil panen dalam kuantitas yang banyak. Sebagai konsekuensinya, terjadi degenerasi kualitas tanah yang berdampak langsung pada menurunnya kualitas dan kuantitas tanaman perkebunan yang sudah dirasakan oleh masyarakat sejak 5 tahun terakhir. Kualitas dan kuantitas panen seperti kelapa, cabe jamu, dan pisang menurun, ditambah pula dengan adanya hama yang menyebabkan panenan tidak sebagus dulu, yang menyebabkan menurunnya pendapatan para petani dari sektor perkebunan. Penggunaan bahan kimia yang berlebihan tersebut, selain menyebabkan chemical pollution yang akan berpengaruh terhadap kualitas tanah, dikhawatirkan juga akan menyebabkan pencemaran air tanah. Hal ini dapat berdampak serius mengingat bahwa air tanah merupakan satu-satunya sumber air bersih yang digunakan oleh penduduk pulau untuk memenuhi kebutuhan hidupnya.

Pola pertanian di Masalembu juga memiliki keunikan tersendiri, terkait dengan aktivitas beternak sapi yang merupakan bagian dari sistem sosial mereka. Pada mulanya, hanya etnis Madura yang beternak sapi di Masalembu. Beternak sapi bagi suku Madura merupakan bagian dari budaya mereka, karena selain memiliki nilai ekonomi juga merupakan lambang status sosial. Sapi Masalembu dianggap memiliki kualitas yang bagus, sehingga para pedagang berani membeli dengan harga tinggi, dan para peternak memperoleh keuntungan yang tinggi pula. Hal ini kemudian menjadi daya tarik ekonomi bagi penduduk Masalembu lainnya, sehingga sapi kemudian mulai diternakkan secara intensif di Masalembu. Ditambah dengan menurunnya kualitas dan kuantitas hasil perkebunan, serta menurunnya harga komoditas perkebunan di pasaran, masyarakat mulai mengembangkan ternak sapi. Tidak hanya suku Madura, tapi penduduk dari etnis lain juga mulai beternak sapi.

Di Pulau Masalembu juga banyak ditemui padang penggembalaan sebagai tempat bagi penduduk untuk menggembalakan ternaknya seperti sapi dan kambing. Padang penggembalaan ini sebenarnya adalah tanah pemerintah, yang dulu direncanakan untuk pembangunan bandara. Karena pembangunan bandara tersebut tertunda, akhirnya padang tersebut menjadi tanah terlantar yang ditumbuhi oleh rumput.

Semakin intensifnya kegiatan perkebunan dan peternakan di Masalembu, selain dipengaruhi oleh pasar yang menjanjikan, juga dikarenakan karena banyak masyarakat yang tidak dapat lagi menggantungkan mata pencaharian mereka semata dari sektor nelayan. Masyarakat Masalembu menyebutkan bahwa hasil tangkapan ikan sekarang menurun banyak jika dibandingkan tahun-tahun sebelumnya, sebagai akibat dari eksploitasi penangkapan ikan yang dilakukan oleh kapal-kapal besar dan pola penangkapan yang tidak memenuhi kaidah sustainability. Selain itu, perubahan iklim juga menyebabkan cuaca yang tak menentu di perairan pulau 
Jawa, yang menyebabkan musim tangkapan ikan juga berubah. Para nelayan Masalembu, yang kebanyakan adalah nelayan tradisional, merasakan bahwa sektor nelayan tidak dapat dijadikan sebagai sumber mata pencaharian utama bagi mereka.

Dalam deskripsi pola pemanfaatan tanah di wilayah Masalembu tersebut, dapat dilihat bahwa penggunaan tanah paling dominan adalah untuk perkebunan, pertanian, peternakan dan permukiman (perumahan, perdagangan, pusat layanan masyarakat/ fasilitas umum maupun untuk keperluan industri). Sektor permukiman dan aktivitas ekonomi terutama berpusat di sekitar dermaga di wilayah selatan pulau, sementara perkebunan dan pertanian terutama terletak di wilayah tengah. Pemerintah setempat maupun warga masyarakat sebenarnya sudah mulai menyadari adanya ancaman konflik kepentingan spasial terkaitdengan penggunaan dan pemanfaatan tanah. Masyarakat juga sudah menyadari adanya ancaman degradasi kualitas tanah yang dapat mengurangi daya dukung tanah terutama yang dirasakan oleh sektor pertanian dan perkebunan. Meskipun begitu, sampai saat ini belum ada pengaturan tertentu terkait zonasi penggunaan tanah di wilayah Masalembu, termasuk juga peraturan terkait penggunaan pemanfaatan tanah yang bersifat sustainable. Sistem masyarakat juga tidak memiliki pengaturan ataupun kebijakan yang bersifat lokalitas (kearifan lokal) terkait dengan penggunaan dan pemanfaatan tanah. Pemerintah Provinsi Jawa Timur juga belum memiliki rencana aksi maupun rencana zonasi terkait penggunaan pemanfaatan tanah di wilayah Masalembu. Selain itu, kontrol terhadap penggunaan dan pemanfaatan tanah dalam melakukan pengelolaan dan pemanfaatan tanah, masyarakat masih berpegang kepada memperoleh keuntungan ekonomi sebesar-besarnya, tanpa berorientasi pada kebutuhan masa depan.

\section{Pengaruh Pemanfaatan Ruang terhadap Dinamika Penggunaan Tanah}

Untuk dapat memahami secara lebih jelas tentang dinamika penggunaan tanah yang terjadi di Pulau Masalembu, digunakan metode DPSIR. Metode ini merupakan merupakan metode yang umum digunakan dalam melakukan evaluasi lingkungan hidup, dan dikembangkan oleh European Environmental Agency (EEA), European Union (EU) dan European Commission (EC) pada tahun 1999 (Jago-on et.al. 2009; Lin, Xue \& Lu 2007). Metode ini merupakan pengembangan dari metode PSR (Pressure-Status-Response) yang dikembangkan oleh Organization for Economic Cooperation and Development (OECD) pada tahun 1993, dan diadopsi oleh EEA menjadi DPSIR (driver-pressure-statusimpact-response). Metode DPSIR telah banyak digunakan untuk melakukan analisis terhadap berbagai macam permasalahan lingkungan, karena dianggap dapat dijadikan sebagai framework yang lebih komprehensif dalam melakukan analisis terhadap hubungan sebab-akibat (driver-D dan impact-I) terhadap berbagai macam permasalahan lingkungan. Dalam metode ini, permasalahan lingkungan ditempatkan sebagai variabel untuk menunjukkan sebab-akibat dan hubungannya dengan aktivitas manusia yang menyebabkan tekanan (pressure- $P$ ) kepada lingkungan, perubahan atas kondisi awal (state-S) dan respon lingkungan atas perubahan tersebut (response-R) (Jago-on et al. 2009).

Dalam contoh Pulau Masalembu, pola penggunaan tanah yang ada saat ini sangat berpengaruhterahadapdinamikadanperubahan yang ada. Dengan memahami secara lebih mendalam mengenai drivers, pressures, states, impacts dan responses, kita akan dapat lebih memahami bagaimana dinamika penggunaan 
tanah di pulau kecil, khususnya Masalembu. Analisis ini akan sangat berguna untuk digunakan sebagai bahan dalam pengambilan rumusan kebijakan pengembangan Rencana Strategis, Rencana Zonasi, dan Rencana Aksi bagi penataan penggunaan dan peruntukan tanah di wilayah pulau kecil. Analisis DPSIR untuk penggunaan tanah Pulau Masalembu dapat dilihat pada Gambar 5.

Gambar 5. Analisis DPSIR untuk Dinamika Penggunaan dan Pemanfaatan Tanah di Wilayah Pulau Masalembu

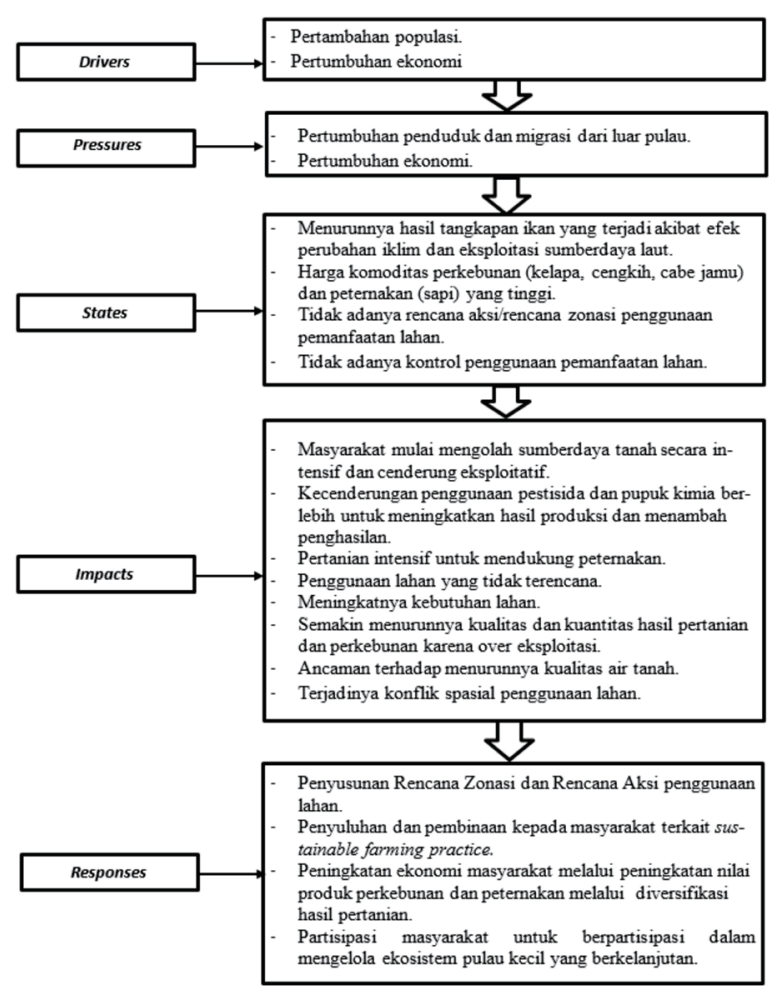

\section{Drivers (faktor pendorong)}

Drivers (faktor pendorong) merupakan suatu kondisi yang menyebabkan terjadinya perubahan, biasanya berupa pertumbuhan ekonomi dan sosial yang bersifat global (Giupponi 2002; Jago-on et al. 2009). Faktor utama yang berperan sebagai drivers dalam pola penggunaan dan pemanfaatan tanah yang ada saat ini adalah pertumbuhan penduduk dan pertumbuhan ekonomi.

Pertumbuhan penduduk, baik yang berasal dari faktor migrasi maupun kelahiran (pertumbuhan penduduk alami), memberikan konsekuensi terhadap kebutuhan tanah yang semakin luas. Tidak hanya digunakan sebagai wilayah permukiman, tetapi juga untuk pengembangan wilayah untuk kegiatan ekonomi, seperti pasar, lokasi industri, pusat pelayanan masyarakat dan fasilitas umum, sektor jasa dan lain sebagainya.

Selain itu, pertumbuhan ekonomi secara global juga berpengaruh terhadap meningkatnya aktivitas ekonomi di Masalembu, dan berlangsung secara simultan dengan pertumbuhan penduduk. Bertambahnya penduduk akan semakin menarik para pendatang untuk bermigrasi ke Pulau Masalembu dan membuka lapangan kerja di sana sebagai pedagang, buruh, maupun pegawai. Selain itu, migrasi musiman yang terjadi saat musim tangkap ikan juga berperan serta dalam meningkatnya aktivitas ekonomi di Masalembu. Pada saat musim tangkap ikan yang biasanya pada bulan April sampai Desember (dengan puncak penangkapan pada bulan Agustus - Oktober), para nelayan musiman (pocokan) yang kebanyakan berasal dari Sulawesi, Lamongan, Gresik, dan sekitarnya berdatangan ke Masalembu dan bekerja sebagai buruh nelayan pada kapal penangkapan ikan.

\section{Pressure (tekanan)}

Definisi mengenai pressures (tekanan) dalam analisis ini adalah segala aktivitas manusia yang memberikan tekanan ataupun mempercepat terjadinya perubahan terhadap kondisi awal lingkungan (Giupponi 2002). Semakin berjalannya waktu, masyarakat semakin merasakan bahwa menangkap ikan (sektor nelayan) tidak dapat memenuhi kebutuhan hidup mereka. Selain karena hasil tangkapan yang menurun (akibat eksploitasi sumberdaya laut yang tidak memperhitungkan keberlangsungan di masa datang), cuaca 
ekstrem juga sering menyebabkan masyarakat Masalembu tidak dapat turun untuk melaut. Hal ini kemudian mulai mendorong masyarakat Masalembu untuk bertani/berkebun. Sejalan dengan hal tersebut, peternakan di Masalembu juga semakin berkembang. Seperti halnya sektor perkebunan, peternakan (sapi) juga memberikan keuntungan yang menjanjikan bagi masyarakat. Berkembangnya ternak sapi ini setidaknya memberikan 3 (tiga) konsekuensi dalam penggunaan dan pemanfaatantanah,yaitu(1) penyediaantempat untuk pemeliharaan sapi yang memenuhi persyaratan lingkungan dan kesehatan (2) penyediaan pakan yang membutuhkan tanah, dan (3) pengelolaan limbah peternakan. Ketiga hal ini kemudian yang berpengaruh terhadap pemanfaatan tanah yang digunakan untuk mendukung peternakan di Masalembu.

Dalam ekosistem pulau kecil yang memiliki keterbatasan ketersediaan tanah, rencana pengembangan dan zonasi pemanfaatan tanah sangatlah penting untuk mencapai pembangunan dan pengelolaan yang berkelanjutan. Meskipun begitu, Masalembu, dan juga banyak pulau kecil berpenghuni lainnya, belum memiliki rencana pengembangan tersebut. Selain itu, sistem masyarakat sendiri belum memiliki nilai ataupun norma yang berkaitan dengan pemanfaatan dan pelestarian lingkungan pulau yang dapat menjamin keberlangsungan ekosistem dan daya dukung lingkungan. Demikian juga dalam pengelolaan perkebunan, pertanian, dan peternakan dilaksanakan secara otodidak oleh masyarakat yang sebagian besar tidak memiliki pengalaman dalam pengolahan tanah. Dengan tidak adanya pendampingan dari pemerintah ataupun pendidikan yang memadai tentang sistem perkebunan yang sustainable, masyarakat tidak mengindahkan keberlangsungan kelestarian lingkungan hidup saat melakukan pengelolaan perkebunan dan peternakan mereka. Penggunaan pupuk artifisial dan pestisida yang berlebihan, tidak adanya sistem pergiliran tanaman, tidak adanya sistem perkebunan dan peternakan komunal, irigasi yang baik, cadangan pakan yang memadai dan lain sebagainya, menyebabkan perkebunan dan peternakan di Masalembu mengalami penurunan baik dalam bentuk kuantitas maupun kualitas. Hal ini berdampak dengan menurunnya pendapatan masyarakat dalam sektor ini, yang malah semakin memicu masyarakat untuk semakin mengeksploitasi tanah mereka secara lebih intensif dan tidak terukur.

\section{State (perubahan atas keadaan awal)}

Dalam analisis DPSIR, state didefinisikan sebagai kualitas lingkungan seperti air, tanah, udara, dan lain sebagainya. State merupakan konsekuensi dari pressures yang mendorong manusia untuk melakukan kegiatan yang berdampak pada berubahnya kualitas lingkungan untuk memenuhi kebutuhan (Giupponi 2002). Dalam kasus Masalembu, akibat dari naiknya tekanan ekonomi akibat menurunnya harga komoditas perkebunan serta kualitas dan kuantitasnya, serta menurunnya hasil tangkapan ikan, masyarakat kemudian mulai beralih untuk memanfaatkan sumber daya tanah sebagai sumber mata pencaharian. Perkebunan dan peternakan mulai dikembangkan secara masif dan intensif. Ditambah dengan mulai meningkatnya harga pasaran komoditas perkebunan dan peternakan, masyarakat mulai bergeser untuk menjadikan kedua hal tersebut sebagai mata pencaharian utama yang lebih dapat diandalkan dibandingkan dengan perikanan. Hal ini juga mendorong masyarakat untuk berinvestasi dalam bentuk tanah, yang berimbas pada naiknya nilai tanah di masyarakat. Dengan tidak adanya pengaturan zonasi pemanfaatan dan penggunaan tanah 
di wilayah Masalembu, masyarakat tidak memiliki perencanaan maupun pengaturan dalam mengelola sumberdaya tanah. Ditambah pula dengan tidak adanya latar belakang agraris dalam kultur nelayan, masyarakat cenderung melakukan pengelolaan tanah secara eksploitatif dan tidak memperhatikan keberlanjutan secara sustainable.

Meningkatnya komoditas perkebunan juga berimbas pada meningkatnya penggunaan pupuk dan pestisida untuk meningkatkan hasil kebun. Akan tetapi, dengan tidak adanya kontrol penggunaan bahan kimia dalam dosis dan takaran yang tepat, hal ini justru menyebabkan masyarakat menggunakannya secara berlebihan. Dalam jangka waktu pendek, hal ini terlihat mampu meningkatkan kualitas dan kuantitas hasil perkebunan. Akan tetapi, dalam jangka waktu panjang, hal ini menyebabkan kualitas dan daya dukung tanah yang menurun akibat adanya polusi tanah, yang justru menyebabkan hasil panen menurun.

Di sektor peternakan, masyarakat juga mulai secara intensif mengembangkan ternak sapiyang berdampak kepadapenggunaantanah untuk rumput. Di Masalembu, selain berkebun, umum dijumpai masyarakat membudidayakan rumput untuk pakan ternak yang dilakukan dengan intensif. Penggunaan pupuk kimia untuk meningkatkan produksi rumput sangat umum dijumpai. Selain itu, masyarakat juga menanam tanaman pertanian seperti kacang, kedelai, dan jagung yang tujuan utamanya adalah digunakan sebagai pakan ternak. Tidak adanya pembinaan dari Pemerintah terkait pengelolaan pertanian, perkebunan, dan peternakan yang berkelanjutan semakin mendorong masyarakat untuk melakukan eksploitasi sumberdaya tanah secala lebih lanjut.

Selain itu, tidak adanya perencanaan dan pengaturan dari Pemerintah yang tertuang dalam rencana zonasi, rencana strategis dan rencana aksi perubahan penggunaan tanah menjadikan Masalembu tidak memiliki mekanisme kontrol dalam manajemen sumberdaya, baik darat maupun laut. Hal ini berimbas kepada pemanfaatan tanah yang tidak terkontrol, dan berorientasi semata pada kepentingan ekonomi.

\section{Impact (dampak yang terjadi)}

Pertumbuhan ekonomi, yang diikuti oleh menurunnya harga komoditas di beberapa sektor perkebunan di Masalembu berdampak pada semakin intensifnya praktek eksploitasi tanah di wilayah tersebut. Lebih lanjut, hal ini memberikan dampak pada merosotnya daya dukung tanah di wilayah serta meningkatnya kebutuhan masyarakat atas tanah untuk melakukan ekspansi perkebunan dan peternakan. Hal ini menimbulkan dampak pada semakin menurunnya kualitas dan kuantitas hasil pertanian dan perkebunan. Lebih lanjut, hal ini dapat pula berakibat terhadap ancaman terhadap menurunnya kualitas air tanah yang terjadi karena polusi bahan kimia dari limbah perkebunan dan peternakan. Dalam jangka panjang, hal ini akan berakibat kepada kualitas ekosistem pulau kecil yang memiliki keterbatasan sumber daya alam dan memerlukan pengelolaan secara berkelanjutan.

\section{Responses (respon terhadap dampak).}

Dalam analisis DPSIR, respon merupakan usaha yang dilakukan oleh masyarakat (baik masyarakat lokal maupun pemerintah/ pembuat kebijakan) dalam menyelesaikan permasalahan seperti yang terdeskripsikan dalam keempat komponen lain. Responses dapat berupa peninjauan kebijakan maupun planning action yang bertujuan untuk menyelesaikan permasalahan lingkungan (Giupponi, 2002). Dalam kasus Masalembu, 
beberapa responses dapat didefinisikan sebagai berikut:

(i) Penyusunan Rencana Zonasi, Rencana Strategis, Rencana Aksi Pengelolaan Penggunaan Pemanfaatan Tanah.

Perencanaan penggunaan dan pemanfaatan tanah merupakan hal mendasar dalam melakukan pengelolaan wilayah pulau kecil yang berkelanjutan. Dengan adanya rencana zonasi, rencana strategis, dan rencana aksi tersebut, satuan wilayah pulau kecil dapat dikelola secara efektif dan efisien berdasarkan prinsip sustainable, baik dari segi ekonomi, sosial maupun lingkungan. Keterbatasan sumberdaya yang dimiliki, serta ciri dan kondisi fisik geografis yang spesifik merupakan pertimbangan penting dalam penyusunan dokumen-dokumen tersebut. Selain itu, faktor eksternal seperti kemampuan adaptasi dan mitigasi terhadap perubahan iklim dan pemanasan global juga merupakan salah satu faktor penting yang perlu dipertimbangkan.

Dalam penyusunan dokumen perencanaan tersebut, sangat penting untuk mempertimbangkan hasil identifikasi dan analisis terhadap drivers, pressures, impacts dan states dalam analisis DPSIR yang telah diuraiakan di atas. Hal ini penting dilakukan supaya perumusan solusi melalui kebijakan dan action planning dapat mempertimbangkan secara komprehensif hubungan antara aktivitas manusia, faktor yang mendasarinya, serta dampaknya terhadap lingkungan hidup. Selain perencanaan yang tertuang dalam dokumen rencana strategis, rencana aksi dan rencana zonasi tersebut, yang tidak kalah penting untuk diperhatikan juga adalah masalah monitoring dan evaluasi pelaksanaannya. Mengingat bahwa pulau kecil memiliki karakteristik sebagai wilayah yang biasanya terpencil, maka penting dipertimbangkan untuk mendesain suatu mekanisme monitoring dan evaluasi yang berbasis partisipatif.

(ii) Penyuluhan dan pembinaan kepada penduduk lokal terkait sustainable farming practice.

Tidak adanya pengetahuan yang memadai tentang praktik sustainable farming, yang salah satunya disebabkan karena lemahnya kultur agraris bagi masyarakat pulau kecil merupakan salah satu faktor pendorong yang menyebabkan eksploitasi sumberdaya daratan berjalan secara terus menerus. Oleh karena itu, pembekalan dan pendampingan terhadap praktek pertanian dan peternakan yang berkelanjutan sangat penting dilakukan oleh pemerintah. Dengan hal ini, diharapkan bahwa masyarakat dapat meningkatkan taraf hidup mereka melalui aktivitas ekonomi di bidang perkebunan, pertanian, dan peternakan dengan tidak melakukan aktivitas yang bersifat eksploitatif terhadap sumber daya alam.

(iii) Peningkatan ekonomi masyarakat melalui peningkatan nilai produk perkebunan dan peternakan melalui diversifikasi hasil pertanian.

Salah satu permasalahan yang dihadapi oleh masyarakat Masalembu adalah tidak adanya teknologi post-processing untuk hasil perkebunan, peternakan, pertanian, maupun perikanan. Masyarakat menjual hasil produksi mereka dalam bentuk mentah, serta tidak ada teknologi penyimpanan untuk mengantisipasi ketika hasil panen melimpah maupun ketika terjadi musim paceklik. Dengan lokasi geografis yang terpencil dan hanya mengandalkan transportasi laut untuk dapat menjual hasil produksi ke luar daerah, kelimpahan maupun kekurangan hasil panen merupakan 
masalah yang hampir selalu dihadapi oleh masyarakat Masalembu.

(iv) Partisipasi masyarakatuntukberpartisipasi dalam mengelola ekosistem pulau kecil yang berkelanjutan.

Partisipasi masyarakat memegang peranan penting dalam pengelolaan pulau kecil. Dengan meningkatkan awareness masyarakat dalam pengelolaan dan pemanfaatan sumberdaya. Didukung dengan adanya peraturan mengenai rencana zonasi, rencana aksi, dan rencana strategis pengelolaan dan pemanfaatan wilayah, partisipasi masyarakat dapat dijadikan sebagai sarana monitoring dan evaluasi dalam implementasinya. Pada praktiknya, pendampingan dari pemerintah memiliki peranan penting, dan partisipasi publik menjadi salah satu kunci utama dalam keberhasilan program tersebut.

\section{Kesimpulan}

Pengelolaan pulau kecil membutuhkan beberapa strategi khusus berkaitan dengan kharakteristik dan kekhususan yang dimilikinya. Oleh karena itu, perencanaan penggunaan dan pemanfaatan sumberdaya, termasuk pula sumberdaya tanah, memegang peranan penting dalam menjaga keberlangsungan ekosistem pulau kecil yang mampu memenuhi kebutuhan penduduknya, baik bagi kebutuhan generasi saat ini maupun generasi mendatang. Dalam kasus Masalembu, tiadanya dokumen rencana aksi, rencana strategis dan rencana zonasi penggunaan pemanfaatan tanah menyebabkan penggunaan tanah yang tidak terencana dan terukur. Eksploitasi tanah sudah terjadi, dan saat ini tanah di Masalembu sudah mulai mengalami penurunan daya dukung, yang ditandai dengan menurunnya kualitas dan kuantitas hasil pertanian. Dalam menentukan strategi pengaturan penggunaan dan pemanfaatan tanah, perlu juga dilakukan revitasilasi fungsi dan daya dukung tanah supaya mampu memenuhi kebutuhan penduduk pulau.

Metode DPSIR, yang secara komprehensif menguraikan hubungan sebab - akibat antara aktivitas manusia dan pengaruhnya terhadap lingkungan, dapat digunakan sebagai alat dalam merumuskan kebijakan dan strategi. Analisis DPSIR terhadap pola penggunaan dan pemanfaatan tanah di wilayah Masalembu menunjukkan beberapa hal berikut: (i) bahwa aktivitas penduduk atas tanah sangat dipengaruhi oleh pertumbuhan ekonomi, perubahan iklim yang menyebabkan pasang surutnya hasil perikanan laut dan pertumbuhan penduduk baik yang terjadi karena kelahiran maupun migrasi; (ii) perubahan iklim yang menyebabkan pasang surut air laut yang tidak menentu, serta eksploitasi sumberdaya laut yang berlebihan dan menyebabkan hasil laut tidak lagi mencukupi untuk memenuhi kebutuhan ekonomi masyarakat, menjadi faktor pendorong masyarakat untuk mulai memanfaatkan tanah sebagai alternatif penghasilan, dan (iii) tidak adanya rencana zonasi dan rencana strategis penggunaan dan pemanfaatan tanah yang membuat pola-pola penggunaan pemanfaatan tanah menjadi tidak terstruktur dan terencana, serta tidak memenuhi prinsip sustainability.

Sebagai kesimpulan, pengelolaan pulau kecil memerlukan strategi komprehensif yang merupakan akumulasi dari action Pemerintah dalam bentuk rencana zonasi, strategi dan rencana aksi, partisipasi masyarakat dalam melakukan praktikpengelolaandanpemanfaatan yang memenuhi kaidah sustainable development, serta kemampuan dalam beradaptasi dan 
mitigasi terhadap perubahan iklim.

\section{Daftar Pustaka}

Abeyratne, R. I 1999, 'Management of the environmental impact of tourism and air transport on small island developing states', Journal of Air Transport Management, 5 (1).

Briguglio, L1995, 'Small island developing states and their economic vulnerabilities', World Development, 23 (9), 1615-1632.

Giupponi, C 2002, From the DPSIR reporting framework to a system for a dynamic and integrated decision making process. Paper presented at the MULINO International Conference on "Policies and tools for sustainable water management in the EU. Venice, Italy.

Huang, J. C. K 1997, 'Climate change and integrated coastal management: a challenge for small island nations'. Ocean E Coastal Management, 37 (1), 95-107. doi: http://dx.doi.org/10.1016/ So964-5691 (97)00042-2

Jago-on, K. A. B., Kaneko, S., Fujikura, R., Fujiwara, A., Imai, T., Matsumoto, T., ... Lee, B 2009, 'Urbanization and subsurface environmental issues: an attempt at DPSIR model application in Asian cities', Science of the total environment, 407(9), 3089-3104.

Kerr, S. A 2005, 'What is small island sustainable development about?', Ocean \& Coastal Management, 48(7), 503-524.

Lin, T., Xue, X.-Z., \& Lu, C.-Y 2007, 'Analysis of coastal wetland changes using the "DPSIR" model: a case study in Xiamen, China', Coastal Management, 35(2-3), 289-303.

Smeets, E., \& Weterings, R 1999, Environmental indicators: Typology and overview, European Environment Agency Copenhagen.

Sutton, P., \& Payne, A 1993, Lilliput under threat: the security problems of small island and enclave developing states. Political Studies, 41(4), 579-593.

Velde, M., Green, S., Vanclooster, M., \& Clothier, B 2007, 'Sustainable development in small island developing states: Agricultural intensification, economic development, and freshwater resources management on the coral atoll of Tongatapu', Ecological Economics, 61(2), 456-468. 